\title{
The Use of Whole Grain Sorghum in Broiler Feeds
}

\section{-Author(s)}

Fernandes EA $^{1}$

Pereira WJS ${ }^{3}$

Hackenhaar $\mathrm{L}^{2}$

Rodrigues $\mathrm{RM}^{4}$

Terra $\mathrm{R}^{5}$

Associate Professor of the Veterinary School of the Federal University of Uberlandia - Av. Pará, 1720 Bloco 2T 38.400-902 Uberlandia - MG - Brasil.

Agroceres Multimix Nutrição Animal Ltda. R.: 1 JN, 1411 Jardim Novo, Caixa Posta 400, 13502-741. Rio Claro-SP.

leandro.hackenhaar@agroceres.com

4 Cobb Vantress Brasil Ltda.

Rafael.Menegatto@cobb-vantress.com

Agronomist - R.: Saturno, 690 Bairro Jardim Brasília, 38.401-390 Uberlandia MG - Brasil.

welder.pereira@bol.com.br

5 Agronomist - R.: Beijos Brancos, 196

Bairro Cidade Jardim, 38.412-204

Uberlandia - MG - Brasil.

raoniterra@hotmail.com

\section{ABSTRACT}

In broiler feed manufacturing, grinding may significantly increase costs due to electric energy use. This study evaluated the performance and the morphometrics of the gastrointestinal tract of broilers. According to a completely randomized experimental design, 2,400 birds $(1,200$ males and 1,200 females) were submitted to five treatments of eight replicates each. Treatments consisted of diets based corn or sorghum as follows: ground corn (A), broken corn (B), ground sorghum (C), ground (50\%) and whole (50\%) sorghum (D) and whole sorghum (100\%; E). Pre-starter feeds (1 to 8 days), based on corn or sorghum, were produced only with ground grains. The study was divided in two trials: males and females. The results were submitted to analysis of variance $(p<0.05)$ and Tukey's test. Feed intake, live weight, feed conversion ratio, and livability of 21- and 42-day-old male and female broilers were not affected by the treatments. This demonstrates that broiler performance is not influenced by sorghum physical form and that broilers fed sorghum-based diets presented similar performance as those fed corn-based diets. Gizzard and small intestine were heavier when whole sorghum grains was included in the diet. It was concluded that whole sorghum grains can be included in broiler feeds with not detrimental effects on performance.

\section{INTRODUCTION}

Sorghum grain is an interesting energy ingredient in poultry diets due to its nutritional composition, which is very similar to corn. Feed is responsible for about two thirds of broiler production costs and, therefore, it is a key factor for the profitability of this activity. It must be noted that not only raw materials contribute to feed cost; feed manufacturing is also important. Grain mills and pelleting presses are the equipments that have the highest impact on feed manufacturing cost due to their high demand of electric energy. Grinding is an important step in feed manufacturing as it determines particle size, which can influence nutrient digestibility and utilization, live performance and feeding cost (Leandro et al., 2001). The effect of corn particle size after grinding (fine, medium and coarse) on the performance of one to sevenday-old chicks and seven to 21-day-old broilers was studied by Nir et al. (1994). These authors observed that the best live performance was obtained when corn particle size was medium and the geometric mean diameter $(G M D)$ of the mixture was $0.769 \mathrm{~mm}( \pm 1.63)$. Another study involving corn particle size compared mash and pelleted feeds with $0.336 \mathrm{~mm}$ GMD $, 0.585 \mathrm{~mm}, 0.856 \mathrm{~mm}$ and $1.120 \mathrm{~mm}$, it was concluded that increasing GMD linearly increased weight gain and feed intake and quadratically improved feed conversion ratio. However, neither particle size nor physical form of the feeds affected carcass yield or leg and 
thighs yield, but the lowest GMD reduced breast yield (Dahlke et al., 2001). Using a feed based on medium crumble corn with a GMD of $0.868 \mathrm{~mm}$, Ribeiro et al. (2002) observed higher feed intake and weight gain and better feed conversion ratio, in addition to higher gizzard weight. No effect was detected on intestinal villi height, abdominal fat, or carcass yield. Vargas et al. (2001) compared mash, crumbled and pelleted feeds and detected better performance of 22 to 35-dayold broilers when crumbled feeds were fed, however, pelleted feeds promoted better results when broilers were at 36 to 42 days of age. In the study of Flemming et al. (2002), 43 to 49-day-old broilers presented better feed conversion ratio and lower mortality when fed pelleted diets, but the best results were obtained at the starter phase, from 15 to 28 days of age. Lopez et al. (2002) studied the effect of separate or joint grinding ingredients in mash and pelleted feeds on the performance of broilers up to 43 days of age and found that feed conversion ratio was better when the pelleted feed was produced with ingredients grounded separately was supplied, whereas mortality was significantly higher when the pelleted feed was produced with joint grinding ingredients. Some studies aiming at reducing the industrial use of mills in feed manufacturing were carried out by Faria Filho et al. (2001). The authors worked with whole and ground wheat grain at inclusion levels of 15, 30 and $45 \%$ in diets for 21 to 49-day-old broilers and demonstrated that the highest inclusion of whole wheat grain did not influence performance or carcass yield. On the other hand, pelleted feeds containing ground or whole triticale grain did not affect weight gain, but the whole grain diet increased gastrointestinal length and gizzard weight (Jones \& Taylor, 2001). In another study, increasing rates of whole wheat grain inclusion promoted a linear increase in gain to feed ratio, increased gizzard weight, but had no effect on carcass yield (Bennett et al., 2002). Considering that larger diameters in hammer mill meshes increase the passage of whole sorghum grains and therefore, their presence in the feed. Murta et al. (2004) fed 8 to 45-day-old broilers with diets containing sorghum grain ground in mills with $1.20 \mathrm{~mm}, 4.763 \mathrm{~mm}, 6.350 \mathrm{~mm}$ and $9.525 \mathrm{~mm}$ diameter meshes and concluded that average body weight, feed intake, liquid feed conversion ratio and livability were not influenced by particle size. In terms of intestinal morphometrics, Maiorka et al. (2002) verified that the development of the intestinal mucosa, increase in the number of villi cells and villi size depend on trophic factors and hormonal regulation. Also, Tarachai \& Yamauchi (2000) observed that the intestinal lumen developed in the presence of nutrients and that this development was characterized by an increase in villi height and in the number of mitotic and extruded cells. The present study aimed at evaluating the live performance and the gastrointestinal morphometrics of male and female broilers fed diets based on whole and ground sorghum grain.

\section{MATERIALS AND METHODS}

The experiment was carried out at the Experimental Poultry Farm of Gloria Farm, of the Federal University of Uberlandia, Uberlandia, MG, Brazil. Birds were housed in a conventional broiler house, containing 80 pens capable of housing 30 adult birds each, at a density of 12.5 birds per square meter. Each pen was equipped with a bell drinker and a trough feeder. The ceiling was made of plastic canvas and the house was equipped with side curtains, foggers, fans, and an electronic panel to monitor environmental temperature. The experimental period was 42 days. Day-old Avian 48 chicks were supplied by Granja Planalto Ltda. Birds were submitted to conventional management practices applied in the commercial farms in that area.

Feeds were formulated according to the nutritional levels recommended by Rostagno et al (2005) and the NRC (1994). Tables 1 and 2 show the ingredients and nutritional composition of the experimental treatments. Diets supplied in each rearing phase were formulated to contain equal energy and nutrient levels. Table 3 shows the geometric mean diameter (GMD) of the experimental diets. The feeding program consisted of three stages: pre-starter diet $(300 \mathrm{~g} / \mathrm{bird})$, starter diet $(900 \mathrm{~g} / \mathrm{bird}$ ) and grower diet (average intake was estimated in $4000 \mathrm{~g} / \mathrm{bird}$ ). Feed and water were offered ad libitum 24 hours per day and artificial lighting was supplied during the entire night period. Pre-starter feeds ( 1 to 8 days), based on corn or sorghum, were manufactured with ground grains and the particle size of the feeds were between $0.780 \mathrm{~mm}$ of GMD.

The experiment was divided in two trials: one with males and the other with females. Birds were distributed according to a completely randomized experimental design, consisting of five treatments with eight replicates of 30 birds each. A number of 1,200 birds per sex were used, with 240 birds per treatment. The following treatments were applied: ground corn $(A)$, broken corn (B), ground sorghum (C), ground (50\%) and whole (50\%) sorghum (D) and whole grain sorghum (E). The following parameters were weekly evaluated per experimental unit (pen): 
Table 1 - Ingredient composition of the experimental diets

\begin{tabular}{|c|c|c|c|c|c|c|c|}
\hline Ingredients & UNIT & \multicolumn{2}{|c|}{ Pre-starter } & \multicolumn{2}{|c|}{ Starter } & \multicolumn{2}{|c|}{ Grower } \\
\hline Corn $8.6 \% C P$ & $\%$ & 54.866 & - & 55.063 & - & 56.109 & - \\
\hline Sorghum 13\%CP & $\%$ & - & 59.525 & - & 62.800 & - & 62.107 \\
\hline $\mathrm{SBM}^{1} 46.5 \% \mathrm{CP}$ & $\%$ & 38.249 & 32.832 & 36.282 & 28.089 & 34.383 & 27.784 \\
\hline Soybean oil & $\%$ & 2.635 & 3.124 & 4.685 & 4.739 & 5.916 & 6.213 \\
\hline Dicalcium phosphate & $\%$ & 1.800 & 1.806 & 1.822 & 1.838 & 1.675 & 1.683 \\
\hline Limestone & $\%$ & 0.993 & 1.019 & 0.998 & 1.034 & 0.922 & 0.952 \\
\hline Salt & $\%$ & 0.446 & 0.466 & 0.425 & 0.448 & 0.427 & 0.446 \\
\hline DL-Methionine & $\%$ & 0.338 & 0.343 & 0.311 & 0.333 & 0.227 & 0.238 \\
\hline L-Lysine $\mathrm{HCl}$ & $\%$ & 0.247 & 0.416 & 0.189 & 0.435 & 0.120 & 0.318 \\
\hline Vit/Min/Additives & $\%$ & $0.200^{2}$ & $0.200^{2}$ & $0.200^{2}$ & $0.200^{2}$ & $0.200^{3}$ & $0.200^{3}$ \\
\hline L-Threonine & $\%$ & 0.045 & 0.070 & 0.026 & 0.082 & 0.022 & 0.057 \\
\hline
\end{tabular}

\section{${ }^{1}$ Soybean meal}

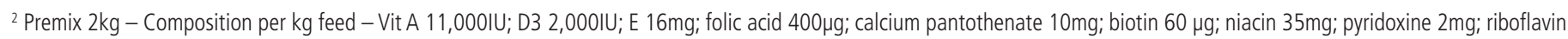
4.5mg; thiamin 1.2mg; B12 $16 \mu g ; \mathrm{K} 1.5 \mathrm{mg}$; Se $250 \mu \mathrm{g}$; choline 249mg; lincomicin 2.200mg/kg; colistin 5.000mg/kg; nicarbazin 25g/kg; monenzin 35g/kg; etoxiquim 120mg; Cu 9mg; Zn 60mg; I 1mg; Fe 30mg; Mn 60mg.

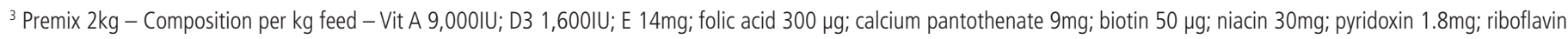
4mg; thiamin 1mg; B12 $12 \mu \mathrm{g} ; \mathrm{K} 3$ 1.5mg; Se $250 \mu \mathrm{g}$; choline 219mg; lincomycin 2.200mg/kg; colistin 3.500mg/kg; salinomycin 33g/kg; ethoxyquin 120mg; Cu 9mg; Zn 60mg; I 1mg; Fe 30mg; Mn 60mg.

Table 2 - Nutritional composition of the experimental diets

\begin{tabular}{lcccc}
\hline Nutrients & UNIT & Pre-starter & Starter & Grower \\
\hline Energy - ME kcal/kg & $\mathrm{kcal}$ & 2960 & 3100 & 3200 \\
\hline Crude protein & $\%$ & 23.97 & 22.24 & 21.80 \\
\hline Calcium & $\%$ & 0.95 & 0.95 & 0.88 \\
\hline Avail. phosphorus & $\%$ & 0.45 & 0.45 & 0.42 \\
\hline Sodium & $\%$ & 0.22 & 0.21 & 0.21 \\
\hline Digestible lysine & $\%$ & 1.30 & 1.20 & 1.10 \\
\hline Digestible Met + Cys & $\%$ & 0.95 & 0.90 & 0.80 \\
\hline Digestible methionine & $\%$ & 0.65 & 0.62 & 0.52 \\
\hline Digestible threonine & $\%$ & 0.78 & 0.73 & 0.70 \\
\hline Digestible tryptophan & $\%$ & 0.25 & 0.23 & 0.27 \\
\hline Digestible arginine & $\%$ & 1.30 & 1.16 & 1.15 \\
\hline
\end{tabular}

Table 3 - Mean particle diameter (GMD) of experimental diets

\begin{tabular}{lcccc}
\hline Treatment & UNIT & Pre-starter & Starter & Grower \\
\hline Ground corn (A) & $\mathrm{mm}$ & 0.788 & 0.797 & 0.809 \\
\hline Broken corn (B) & $\mathrm{mm}$ & - & 1.102 & 1.175 \\
\hline Ground sorghum & $\mathrm{mm}$ & 0.793 & 0.821 & 0.846 \\
\hline $\begin{array}{l}\text { Ground:whole } \\
\text { sorghum }\end{array}$ & $\mathrm{mm}$ & - & 1.357 & 1.395 \\
\hline $\begin{array}{l}\text { Whole sorghum } \\
\mathrm{mm}\end{array}$ & - & 1.765 & 1.865 \\
\hline
\end{tabular}

A - Average feed intake: at the beginning of each week, the amount of feed per pen stored in the bucket and the amount in the feeder were weighed (feed offer). At the end of the same week, feed residues in the feeder and in the bucket were weighed (feed residue). Feed intake was then calculated as the difference between feed offer and feed residue divided by the number of birds in the pen.

B - Average live weight: All birds in each pen were weekly weighed. Average live weight was calculated as pen weight divided by the number of birds in the pen. Mortality was recorded in the pen file and dead birds were weighed. Total weight of dead birds per pen was used on the calculation of corrected feed conversion ratio.

C - Feed conversion ratio: The ratio between feed intake and live weight was calculated per pen, and it was corrected by adding total weight of the dead birds to total live weight, and subtracting the result from total live weight of day-old-chicks per pen.

D - Livability: Percentage of live birds at the end of the experimental period relative to the initial number of birds.

When birds were 42 days of age, two males per pen were randomly removed ( 16 birds per treatment), identified with a plastic band and sent to the processing plant, where they were slaughtered and eviscerated. Carcasses were cut up into traditional parts to measure yields. Gizzard, small intestine, and ceca were separated, their contents were removed and these organs were measured, weighed in a precision scale used in morphometric studies.

The results were submitted to analysis of variance and to the F-test at 5\% significance level. Means were compared by Tukey test (ESTAT - V 2.0). 
TABLE 4 - Performance of 21-day-old broilers fed diets containing ground, mixed and whole grains.

\begin{tabular}{cccccccccc}
\hline & \multicolumn{2}{c}{ Feed intake $(\mathrm{g})$} & \multicolumn{2}{c}{ Live weight $(\mathrm{g})$} & \multicolumn{2}{c}{ Corrected FCR } & \multicolumn{2}{c}{ Livability $(\%)$} \\
\hline Treatment & Male & Female & Male & Female & Male & Female & Male & Female \\
\hline A & 1106 & 1126 & 856 & 794 & 1.356 & 1.493 & 99.17 & 97.08 \\
\hline B & 1106 & 1122 & 853 & 791 & 1.366 & 1.492 & 98.75 & 97.50 \\
\hline C & 1119 & 1100 & 858 & 802 & 1.367 & 1.449 & 98.33 & 99.17 \\
\hline D & 1118 & 1092 & 834 & 792 & 1.413 & 1.458 & 98.33 & 99.58 \\
\hline E & 1121 & 1125 & 833 & 776 & 1.406 & 1.513 & 97.92 & 97.50 \\
\hline GM & 1114 & 1113 & 847 & 791 & 1.382 & 1.481 & 98.50 & 98.17 \\
\hline CV (\%) & 3.54 & 3.15 & 3.21 & 4.56 & 4.06 & 5.15 & 2.64 & 2.83 \\
\hline
\end{tabular}

GM - General mean

\section{RESULTS AND DISCUSSION}

Feed intake, live weight, feed conversion ratio and livability of 21-day-old birds of both sexes were not affected by the treatments ( $>0.05)$, whether feed contained ground, broken or whole grains (Table 4).

In the present experiment, no differences in performance parameters were observed when ground (C), partially ground (D) or whole (E) sorghum diets were fed, as well as when ground (A) or broken corn (B) was supplied. These results, however, are different from those obtained by Dahlke et al (2001) and Ribeiro et al (2002), who found that performance improved as mean particle diameter increased $(0.868 \mathrm{~mm}$ and $1.120 \mathrm{~mm} G M D)$. Also evaluating 21-d-old broilers, Nir et al. (1994) observed better performance when birds were fed a diet containing medium-particle corn $(0.769 \mathrm{~mm} \mathrm{GMD})$ in comparison to a diet with finely ground corn.

During the first eight days of life, all birds received pre-starter diets based on corn and ground sorghum

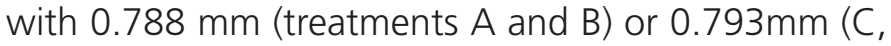
$D$ and E) GMD. Birds started to be fed coarse particles only in the starter diets, supplied between eight and 21 days of age. The diets with different particle sizes were offered only for 14 days, and perhaps this period was not long enough to result in performance differences, which may explain the differences with literature findings.

Table 5 shows feed intake, live weight, liquid feed conversion ratio (FCR) and livability of 42-day-old broilers. These results demonstrate that the different particle size of diets based on sorghum (ground, partially ground and whole grain) did not affect the performance of male or female broilers. The performance of the birds fed sorghum-based diets was also similar to those obtained with diets based on ground or broken corn (Table 5).

Only the corrected FCR of the females fed the diet containing $50 \%$ ground sorghum and $50 \%$ whole sorghum (Treatment D) was significantly better than those fed ground corn (Treatment $A ; P<0.05$ ). These findings are consistent with those obtained by Faria Filho et al. (2001), who included up to $45 \%$ whole wheat grain in diets fed to broilers from 21 days of age up to market with no effect on live performance, and with those of Jones and Taylor (2001), who did not detect any effect of the inclusion of whole triticale grains in pelleted diets on weight gain. Murta et al. (2002) worked with diets containing sorghum grain of different particle sizes $(1.20 \mathrm{~mm}$ to $9.525 \mathrm{~mm}$ mesh) and did not find performance differences. If we consider that the inclusion of whole sorghum grain in the feed did not affect the parameters feed intake,

TABLE 5 - Performance of 42-day-old broilers fed diets containing ground, mixed and whole grains.

\begin{tabular}{|c|c|c|c|c|c|c|c|c|}
\hline \multirow[t]{2}{*}{ Treatment } & \multicolumn{2}{|c|}{ Feed intake $(\mathrm{g})$} & \multicolumn{2}{|c|}{ Live weight $(\mathrm{g})$} & \multicolumn{2}{|c|}{ Corrected FCR } & \multicolumn{2}{|c|}{ Livability (\%) } \\
\hline & Male & Female & Male & Female & Male & Female & Male & Female \\
\hline A & 4399 & 3810 & 2570 & 2268 & 1.669 & $1.672^{\mathrm{a}}$ & 95.41 & 96.67 \\
\hline$B$ & 4452 & 3822 & 2651 & 2292 & 1.635 & $1.658^{\mathrm{ab}}$ & 94.16 & 96.25 \\
\hline C & 4437 & 3787 & 2652 & 2260 & 1.636 & $1.663^{\mathrm{ab}}$ & 94.58 & 97.08 \\
\hline $\mathrm{D}$ & 4414 & 3709 & 2687 & 2309 & 1.605 & $1.599^{b}$ & 94.58 & 97.93 \\
\hline$E$ & 4343 & 3782 & 2667 & 2336 & 1.583 & $1.602^{a b}$ & 93.75 & 95.83 \\
\hline GM & 4409 & 3782 & 2645 & 2293 & 1.626 & 1.639 & 94.50 & 96.75 \\
\hline $\mathrm{CV}(\%)$ & 5.05 & 4.33 & 3.32 & 3.13 & 3.80 & 3.00 & 4.30 & 4.00 \\
\hline
\end{tabular}

GM - General mean

Means in the same column followed by different letters are significantly different $(p<0.05)$ 
live weight, liquid feed conversion ratio or livability, and assuming that not submitting grains to grinding represents electric energy savings, these results are very promising.

Table 6 presents gizzard and intestine biometric results of male broilers of treatments $A, C, D$ and $E$. Unfortunately, half of the birds of treatment $B$ were mistakenly removed from the processing line and, consequently, their data could not be evaluated.

It was observed that the inclusion of $50 \%$ or $100 \%$ of whole sorghum grain in the diet promoted a significant increase in gizzard and small intestine weight. The ceca were not significantly influenced by sorghum particle size.

Table 6 - Effect of feed particle size on the gastrointestinal weight and length of 42-day-old male broilers.

\begin{tabular}{lccccc}
\hline Treatments & Gizzard & \multicolumn{2}{c}{ Small intestine } & \multicolumn{2}{c}{ Ceca } \\
\cline { 3 - 6 } & $(\mathrm{g})$ & $(\mathrm{g})$ & $(\mathrm{cm})$ & $(\mathrm{g})$ & $(\mathrm{cm})$ \\
\hline Ground corn (A) & $35.807_{\mathrm{b}}$ & $46.476_{\mathrm{b}}$ & 166.53 & 6.957 & $17.97_{\mathrm{b}}$ \\
\hline $\begin{array}{l}\text { Ground } \\
\text { sorghum (C) }\end{array}$ & $38.114_{\mathrm{b}}$ & $48.410_{\mathrm{ab}}$ & 170.84 & 7.084 & $18.97_{\mathrm{ab}}$ \\
\hline $\begin{array}{l}\text { Ground: whole } \\
\text { sorghum (D) }\end{array}$ & $42.101_{\mathrm{a}}$ & $51.810_{\mathrm{ab}}$ & 173.75 & 7.102 & $18.81_{\mathrm{ab}}$ \\
\hline $\begin{array}{l}\text { Whole } \\
\text { sorghum (E) }\end{array}$ & $44.468_{\mathrm{a}}$ & $52.911_{\mathrm{a}}$ & 175.28 & 7.379 & $19.53_{\mathrm{a}}$ \\
\hline General mean & 40.122 & 49.902 & 171.60 & 7.131 & 18.82 \\
\hline CV (\%) & 10.62 & 12.24 & 7.98 & 17.23 & 7.57 \\
\hline
\end{tabular}

Means in the same column followed by different letters are significantly different $(p<0.05)$

These findings are consistent with those of Jones and Taylor (2001), Ribeiro et al. (2002) and Bennett et al. (2002). In the present study, small intestine length was not influenced by the dietary inclusion of whole grains, differently from the results obtained by Jones \& Taylor (2001). However, gastrointestinal tract weight significantly increased in the presence of whole grain sorghum (E), which could be explained by a greater development of the intestinal mucosa, as demonstrated by Tarachai \& Yamauchi (2000) and Maiorka et al. (2002). Cecum length significantly increased when whole sorghum grain was included in the diets. The heavier gizzards ( $D$ and $E$ ) and small intestines and the longer ceca $(E)$ recorded as a function of the presence of whole grains in the diet ( $D$ and $E$ ) may be explained by the response of the bird's GIT to the particle size of an ingredient that remains longer inside the gizzard, demonstrating an anatomic-physiological effort to maximize the digestive process.

\section{CONCLUSIONS}

The use of whole sorghum grain in feeds is feasible for broilers older than nine days of age and it is not detrimental to performance. Performance is similar when broilers are fed diets based on corn or on sorghum. Feed particle size (whole grains) increases gizzard and small intestine weights.

\section{ACKNOWLEDGEMENTS}

The authors thank Cargill Agrícola Ltda., Faculdade de Medicina Veterinária (UFU), Fundação de Desenvolvimento Agropecuário (FUNDAP), Monsanto do Brasil Ltda., and Planalto Ltda. for their support.

\section{REFERENCES}

Bennett CD, Classen HL, Ridell C. Feeding broiler chickens wheat and barley diets containing whole, ground and pelleted grain. Poultry Science 2002;81:995-1003.

Dahlke F, Ribeiro AML, Kessler AM, Lima AR. Tamanho da partícula do milho e forma física da ração e seus efeitos sobre o desempenho e rendimento de carcaça de frangos de corte. Revista Brasileira de Ciência Avícola 2001;3(3):241-248.

ESTAT - Sistema para Análise Estatística. Versão 2.0. Jaboticabal: Polo Computacional,Departamento de Ciências Exatas, UNESP; 1993.

Faria Filho DE, Sakomura NK. Junqueira OM, Jacob DV, Angelo JC. Utilização de trigo em grão ou moído em dietas para frangos de corte. Revista Brasileira de Ciência Avícola 2001;3(2): 173-180.

Flemming JS, Montanhini Neto R, Arruda JS, Franco S.G. Efeito da forma física e do valor de energia metabolizável da dieta sobre o desempenho de frangos de corte. Archives of Veterinary Science 2002;7(2):27-34.

Jones GPD, Taylor RD. The incorporation of whole grain into pelleted broiler chicken diets: production and physiological responses. British Poultry Science 2001;42(4):477-483.

Leandro NSM, Stringhini JH, Café MB, Orsine GF, Rocha AC. Efeito da granulometria do milho e do farelo de soja sobre o desempenho de codornas japonesas. Revista Brasileira de Zootecnia 2001;30(4):12661271.

López CAA, Baião NC. Efeitos da moagem dos ingredientes e da forma física da ração sobre o desempenho de frangos de corte. Arquivo Brasileiro de Medicina Veterinária e Zootecnia 2002;54(2):189-195.

Maiorka A, Boleli IC, Macari M. Desenvolvimento e reparo da mucosa intestinal [cap 8]. In: Macari M, furlan RL, Gonzáles E. Fisiologia aviária aplicada a frangos de corte. Jaboticabal: FUNDEP, UNESP; 2002. p.113123.

Murta GPO, Fernandes EA, Olegário MMM, Silva CB, Pereira PC. Efeito da moagem do sorgo grão sobre o desempenho de frangos de corte. Revista Brasileira de Ciência Avícola-Prêmio Lamas 2001;(Supl 6):32.

National Research Council. Nutrients requirements of poultry. $9^{\text {th }}$ ed. Washington DC; 1994.

Nir I, Shefet G, Aaroni Y. Effect of particle size on performance. 1. Corn. Poultry Science 1994;73(1):45-49. 
Ribeiro AML, Magro N, Penz JR AM. Granulometria do milho em rações de crescimento de frangos de corte e seu efeito no desempenho e metabolismo. Revista Brasileira de Ciência Avícola 2001;4(1):001-007.

Rostagno HS, Albino LFT, Donzele JL, Gomes PC, Oliveira RF, Lopes DC, Ferreira AS, et a. Tabelas brasileiras para aves e suínos: composição de alimentos e exigências nutricionais. $2^{\text {nd }}$ ed. Viçosa, MG: Universidade Federal de Viçosa; 2005

Tarachai $\mathrm{P}$, Yamauchi K. Effects of luminal nutrient absorption, intraluminal physical stimulation and intravenous parental alimentation on recovery responses of duodenal villus morphology following feed withdrawal in chickens. Poultry Science 2000;79:1578-1585

Vargas GD, Brum PAR de, Fialho FB, Rutz F, Bordin R. Efeito da forma física da ração sobre o desempenho de frangos de corte machos. Revista Brasileira de Agrociência 2001;7(1):42-45. 